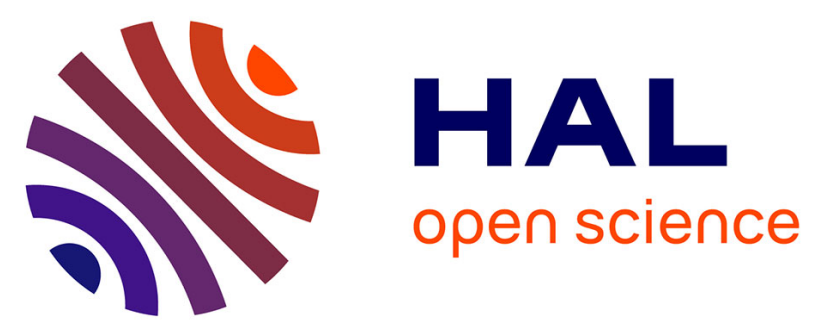

\title{
Identification of potential recruitment bottlenecks in larval stages of the giant fan mussel Pinna nobilis using specific quantitative PCR
}

Karl B Andree, Sergio Trigos, Nardo Vicente, Noelia Carrasco, Francesca Carella, Patricia Prado

\section{To cite this version:}

Karl B Andree, Sergio Trigos, Nardo Vicente, Noelia Carrasco, Francesca Carella, et al.. Identification of potential recruitment bottlenecks in larval stages of the giant fan mussel Pinna nobilis using specific quantitative PCR. Hydrobiologia, 2018, 818 (1), pp.235-247. 10.1007/s10750-018-3616-x . hal-01769808

\section{HAL Id: hal-01769808 \\ https://hal.science/hal-01769808}

Submitted on 15 Mar 2019

HAL is a multi-disciplinary open access archive for the deposit and dissemination of scientific research documents, whether they are published or not. The documents may come from teaching and research institutions in France or abroad, or from public or private research centers.
L'archive ouverte pluridisciplinaire HAL, est destinée au dépôt et à la diffusion de documents scientifiques de niveau recherche, publiés ou non, émanant des établissements d'enseignement et de recherche français ou étrangers, des laboratoires publics ou privés. 


\title{
Identification of potential recruitment bottlenecks in larval stages of the giant fan mussel Pinna nobilis using specific quantitative PCR
}

\author{
Karl B. Andree, Sergio Trigos, Nardo Vicente, Noelia Carrasco, Francesca Carella, Patricia Prado \\ K. B. Andree $(\square) \cdot$ N. Carrasco $\cdot$ P. Prado \\ IRTA-Aquatic Ecosystems, Ctra, Poble Nou Km 5.5, 43540 Sant Carles de la Ra`pita, Tarragona, Spain e-mail: karl.andree@irta.es \\ N. Vicente \\ Institut Méditerranéen de la Biodiversité et d'Ecologie Marine et Continentale (IMBE), Aix Marseille Université, Avignon Université, \\ CNRS, IRD, Marseille, France \\ Institut Océanographique Paul Ricard, Ile Des Embiez, 83140 Six Fours Les Plages, France \\ S. Trigos \\ Innovation Network in Aquaculture Industries of the Valencian Community (RIIA-CV), Avda. Naranjos s/n, Edificio Colegio Mayor \\ Galileo Galilei, Local 15, 46022 Valencia, Spain \\ F. Carella \\ Department of Biology, University of Naples Federico II, Naples, Italy
}

\begin{abstract}
Pinna nobilis is an endangered species of fan mussel found along coastal Mediterranean waters requiring special attention for conservation. Popula-tions are restricted in number, due to anthropogenic disturbances, disease, and in some areas, low rates of recruitment. To date, the difficulties associated with the identification of planktonic stages have prompted the use of benthic collectors as a proxy for quantifying larval supply, despite important information being lost regarding planktonic processes. We present evidence of spawning utilizing a qPCR assay developed for detect-ing genomic DNA of $P$. nobilis to enable specific identification of planktonic stages to augment knowl-edge of $P$. nobilis life history. In the Ebro Delta, Spain, it has been used to study what might be limiting their

reproduction locally. We demonstrate the ability to differentiate DNA of $P$. nobilis from other bivalve mollusks and distinguish between fertilized and unfer-tilized eggs of $P$. nobilis, which may be a crucial point for understanding the low level of recruitment seen in this natural population. We also show evidence of larval presence during the expected spawning period, although abundance in positive samples were so low that they pose new questions about factors controlling the availability of planktonic stages of $P$. nobilis.
\end{abstract}

Keywords Shellfish larvae · Western Mediterranean · Pinna · qPCR 


\section{Introduction}

The endangered fan mussel Pinna nobilis L. is the largest and one of the most emblematic marine Mediterranean bivalves, reaching sizes of up to 120 $\mathrm{cm}$, and 20 years of age (Zavodnik et al., 1991; Butler et al., 1993). Its endemic nature prompted an inclusion within the list of endangered Mediterranean species at the Barcelona convention (Protocol ASPIM Annex 2). The European Council Habitats Directive 92/43/EEC, on conservation of natural habitats and the wild fauna and flora, proclaims that $P$. nobilis is strictly protected under Annex IV EEC 1992, and all forms of deliberate capture or killing of fan mussels are prohibited by law (Centoducati et al., 2007). Yet, poaching activities continue (e.g., Siletic \& Peharda, 2003), and an indirect threat is still imposed by a multiplicity of anthropogenic stressors such as fish-eries that use trawling, eutrophication of coastal embayments (Marba' et al., 1996), and emergent diseases. For instance, a significant large-scale mor-tality occurred during the summer of 2016 along the Spanish Mediterranean coast and the Balearic Islands, possibly associated with outbreaks of a haplosporidan parasite (Darriba, 2017). In certain areas such as the Mljet lakes (Croatia), and the Mar Grande Basin (Italy) $P$. nobilis populations have been reported to experience some increase (e.g., Siletic \& Peharda, 2003; Centoducati et al., 2007), although common abundances do not usually exceed one individual per $100 \mathrm{~m}^{2}$ (Guallart \& Templado, 2012).

Recruitment rates of $P$. nobilis within benthic collectors are often used as a proxy for larval availability (e.g., Kersting \& Garc1'a-March, 2007), but planktonic abundances per se have never been evaluated in any region. To distinguish bivalve species by larval morphology is not easily achieved as the veliger larval morphology reflects more ancestral states than adult morphology and therefore makes identification to species level of the plankton stages unlikely (Malchus \& Sartori, 2013). Yet, the abundance of planktonic stages of $P$. nobilis in open waters is not necessarily the same as in the benthos, and the pelagic-benthic coupling may not affect all species equally (Ebert, 1983). For instance, it has been shown that large-scale environmental factors (e.g., currents, nutrients, temperature) were the most influential on larval availability, whereas benthic abundances were determined by the complexity of spatial distribution of preferential substrates for settlement, predation and migration occurring at smaller spatial scales (Prado et al., 2012).

Alfacs Bay (Ebro Delta, Catalonia) has been reported to contain the second largest population of $P$. nobilis in the Mediterranean with an estimated number of over 90,000 individuals, with peak densities of up to 20 individuals per $100 \mathrm{~m}^{2}$, and mean densities of $1.61 \mathrm{~m}^{-2}$ (Prado et al., 2014). The population is characterized by an extremely superficial distribution of individuals growing over extensive meadows of the seagrass Cymodocea nodosa, at depths from $20 \mathrm{~cm}$ down to $130 \mathrm{~cm}$ (Prado et al., 2014). Although this is close to the shallow distribution limit established for the species (ca. 0.5-60 m; Butler et al., 1993), it usually displays peak densities at depths from ca. 3-4 to 14-15 m (Garc1'a-March \& Kersting, 2006; Katsanevakis, 2007; Coppa et al., 2013). Those animals inhabiting depths of less than $1 \mathrm{~m}$ are only rarely reported (see Zakhama-Sraieb et al., 2011). The origin of the Alfacs Bay population is uncertain and was apparently reduced to a few isolated individuals during the 1990s (J. Romero, pers. comm.), until a major recruitment event occurred. Nearby locations such as the Sierra de 1'IRTA, Columbretes Islands, or L'Ampolla de Mar may be possible sources for larval recruitment. Currently, the population displays a very homogeneous size structure (between 40 and $60 \mathrm{~cm}$ ) and lacks individuals smaller than $20 \mathrm{~cm}$. This suggests an important limitation in the availability of larvae and/or high mortality during the processes of benthic settlement and recruitment (Prado et al., 2014). The distribution of individuals in the bay is highly variable, and includes large unpopulated areas. This is presumably due to changes in habitat and/or the chemical characteristics of the water of the bay (e.g., agricultural runoff from extensive rice cultivation in the northern shore of the bay, and salt evaporation ponds along the inner part of the southern shore; Prado et al., 2014). Therefore, developing an adequate tool for evaluating larval availability and fertilization success will aid in assessing the factors driving the demographics of the population within the bay (but may also be applicable to other regions). Such information could be very helpful for the implemen-tation of conservation programs that take into account how planktonic processes could be effected by local factors, such as agricultural runoff and/or the density of adults. 
The use of quantitative polymerase chain reaction (qPCR) has proven to be useful for detection of low abundance and cryptic species in aquatic environments (Ficetola et al., 2008), or where morphological characteristics cannot be used for species discrimination (Andree et al., 2011). More recently, qPCR has been shown to be an effective and sensitive tool for the detection and quantification of planktonic organisms (e.g., Vadopalas et al., 2006; Endo et al., 2010), whose identification through classical observational methods is extensive and arduous. More relevantly, qPCR has been used for the detection and quantification of larvae in other species of commercially important mollusks such as abalone (Vadopalas et al., 2006) and invasive alien species such as zebra and golden mussels (Frischer et al., 2002; Endo et al., 2009). For these purposes planktonic abundances were estimated by plotting threshold cycle $\left(C_{\mathrm{t}}\right)$ values on the standard curve obtained from template DNA extracted from serial dilution of eggs/larvae (see for instance, Endo et al., 2010). Therefore, one limitation to the devel-opment of such methods relies on the availability of planktonic material of the target species for construction of a proper calibration curve. Moreover, the interpretation of results requires some consideration be given to the chromosome endowment of the analyzed sample (fertilized or non-fertilized egg or larva), and the copy number of the genomic region being targeted by the assay.

A more direct need for assay development is a genetic marker that is specific and easily isolated. Ribosomal RNA genes occur in multiple copies within the genome, with many conserved regions interspersed with more variable portions, making them ideal for such use. Ribosomal DNA genes are one of the most common markers used for clarification of taxonomic assignment. There exist in genetic databases an ample variety of these sequences from many species whose genomes are otherwise completely unknown. The non-structural intergenic spacers have been shown to be especially useful for fine-scale phylogenetic assessment. The high rate of mutation during evolutionary time scales in ITS regions of the rDNA cistron, as compared to coding regions, means that there is a lower probability of encountering a similar sequence in closely related species to which species-specific primers can bind. Depending on the species under study this region may be useful as a genetic marker for population assignment (Wren et al., 2000).

In the particular case of $P$. nobilis, the apparent short period of larval planktonic life of between 5 and 10 days (De Gaulejac \& Vicente, 1990) may help reduce variability in the number of larval cells among individuals collected at different time points. Among some commercial bivalve species studied more closely, a "low ...but uniform" growth rate has been observed (Robert \& Gerard, 1999), but only few data exist for $P$. nobilis. The fertilized oocytes are $\sim 50$ $\mu \mathrm{m}$ in size and in 5-10 days when they are ready to settle to the benthos they reach a diameter of $\sim 100$ $\mu \mathrm{m}$ (Trigos, 2017). The modest increase in size suggests the number of cells should not vary considerably between different planktonic larvae. Hence, it was considered that quantitative PCR could be applied for the efficient detection and quantification of $P$. nobilis eggs and larvae. This leads to the following specific objectives: (1) to identify a species-specific marker for a qPCR assay; (2) to design primers for specific identification of $P$. nobilis, which utilize genomic regions that are well conserved at the species level, but with high interspecific variability to avoid false positives in screening environmental samples (Andree et al., 2011; Dejean et al., 2011; Wilcox et al., 2013); (3) to establish a useful calibration curve for fertilized and unfertilized eggs and larvae of $P$. nobilis that allow interpretation of $C_{\mathrm{t}}$ values from field samples; and (4) to determine a field sampling method most effective for detecting and quantifying the presence of $P$. nobilis larvae or gametes. Meeting these objectives will provide the techniques for more expansive evaluations in other Mediterranean regions hosting $P$. nobilis.

\section{Materials and methods}

\section{Sample collection}

Tissue samples were collected from living $P$. nobilis in situ by pinching off a small piece of mantle using a 15-cm-long hemostat inserted between semi-opened valves, and preserving in 70\% ethanol until later DNA extraction (Fig. 1). For the purpose of obtaining DNA sequence data, samples were initially collected from two sites: Alfacs Bay $(n=21)\left[40^{\circ} 35^{\prime} 40.59^{\prime \prime} \mathrm{N}\right.$; $\left.0^{\circ} 39^{\prime} 37.36^{\prime \prime} \mathrm{E}\right]$ and to the south, outside of the bay, 


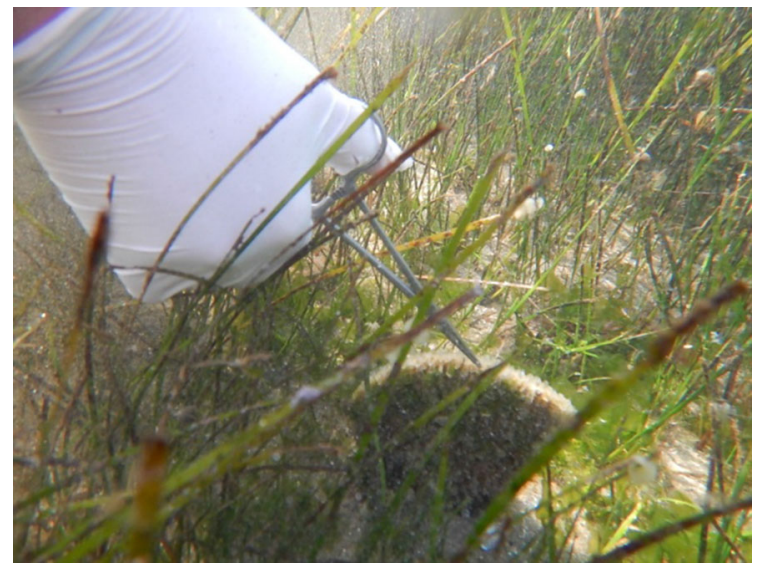

Fig. 1 Non-lethal sample collection in situ from P. nobilis, using a hemostat

in the port of Las Casas de Alcanar $(n=9)$ [40 $\left.33^{\prime} 09.32^{\prime \prime} \mathrm{N} ; 0^{\circ} 31^{\prime} 53.64^{\prime \prime} \mathrm{E}\right]$ (Fig. 2).

Initially (from 06/01/16 to 07/01/16), only $500 \mathrm{ml}$ water samples ( $n=3$ per site) were collected immediately adjacent to individual adult animals in situ and later filtered through a $10 \mu \mathrm{m}$ nylon mesh. The mesh was rinsed with $400 \mu$ l lysis buffer to collect material for extraction and kept frozen until further processing. In June, when the first $500 \mathrm{ml}$ samples were collected, they were also examined in the lab by light microscopy, and bivalve larvae identified and counted. However, the observation of single larvae in this volume was rare, therefore from $07 / 15 / 16$ to $10 / 01 / 16$, sampling was conducted every 15 days using a plankton net having an open aperture of $0.2 \mathrm{~m}$ diameter and $30 \mu \mathrm{m}$ size mesh (sufficient for catching eggs and larvae). Samples were collected as before in 3 sites ( $n=3$ replicates per site) by walking ca. $30 \mathrm{~m}$ over the seagrass bed of Cymodocea nodosa, equivalent to a filtration volume of $3.77 \mathrm{~m}^{3}$. Samples were preserved in $70 \%$ ethanol and separated into different size fractions: $40 \mu \mathrm{m}$ (egg sizes ranging from 40 to 70 $\mu \mathrm{m}$ and larval sizes from ca. 80-110; Trigos et al., 2017), 125 and $250 \mu \mathrm{m}$ (to check for additional entangled material) using sieve nets. A preliminary observation of each fraction and sample was also conducted in order to determine the abundance of eggs and larvae and the feasibility of their separation. For eggs, given the large abundance and the absence of identification keys that could aid the distinction from other marine invertebrates, separation was considered unfeasible and not conducted. However, all bivalve larvae observed were collected. When the number was too large for accurate counting (hundreds to thousands of individuals), fractions were divided into smaller subsamples $(1 / 2,1 / 4$, or $1 / 8$ depending on the number), and later the total number of larvae in the sample calculated from $\mathrm{Ct}$ values obtained from these subsamples. Individual larvae were separated under the dissecting microscope (NIKON SMZ1500) using a zooplankton "micro-spoon" fabricated from a thin piece of platinum wire to which a loop of ca. $80 \mu \mathrm{m}$ diameter was formed. All separated larvae from each replicate sample were kept in $1.5 \mathrm{ml}$ vials with $30 \mu \mathrm{l}$ of Qiagen AE buffer (to ease larvae release from the spoon) and stored at $-80{ }^{\circ} \mathrm{C}$ until later DNA extraction (see below).

For the construction of calibration curves we used a limited supply of ethanol preserved D-veliger larvae (all of these ca. $85 \mu \mathrm{m}$ in length), and fertilized and unfertilized egg samples of $P$. nobilis (Fig. 3) collected from an in vitro reproduction study performed previously in another institute (Trigos et al., 2017) (Fig. 4). This same supply of eggs previously produced in the lab were also used for creating pseudofield samples to test the likelihood of collecting eggs from seawater and detecting the presence of $P$. nobilis DNA. This was done by collecting 10 eggs or 1 egg and placing them into different volumes of filtered seawater $(15,50$, or $500 \mathrm{ml})$ that were filtered through a $10 \mu \mathrm{m}$ nylon mesh for subsequent DNA extraction and testing by qPCR. Filters were rinsed with $400 \mu \mathrm{l}$ of lysis buffer containing $40 \mu \mathrm{l}$ proteinase $\mathrm{K}$ solution (Ref\# 19131, Qiagen Valencia, CA, USA) to collect filtrate for DNA extraction. All of these experiments were performed with a somewhat low number of replicates and total $\mathrm{N}$ since the material used, eggs and larvae, was produced from experiments in $P$. nobilis captive spawning. Spawning for this species is still somewhat at the experimental stage, and not of a commercial nature as it is for cultured species such as Crassostrea gigas. This limited supply of eggs and larvae limited the number of experiments and the number of replicates per experiment.

DNA extraction, amplification, sequencing, and qPCR amplification

Extraction of DNA utilized the Qiagen Blood and Tissue Kit (Ref\# 69506, Qiagen, Valencia, CA, USA), and for all samples the $A_{260 / 280}$ ratios were examined 
Fig. 2 Map indicating the location of each sampling zone within the study site (Z1 zone of high abundance, $Z 2$ zone of intermediate abundance, $Z 3$ zone of low abundance). Dotted lines indicate the irrigation canals used for managing water flows through the rice fields in the Ebro delta
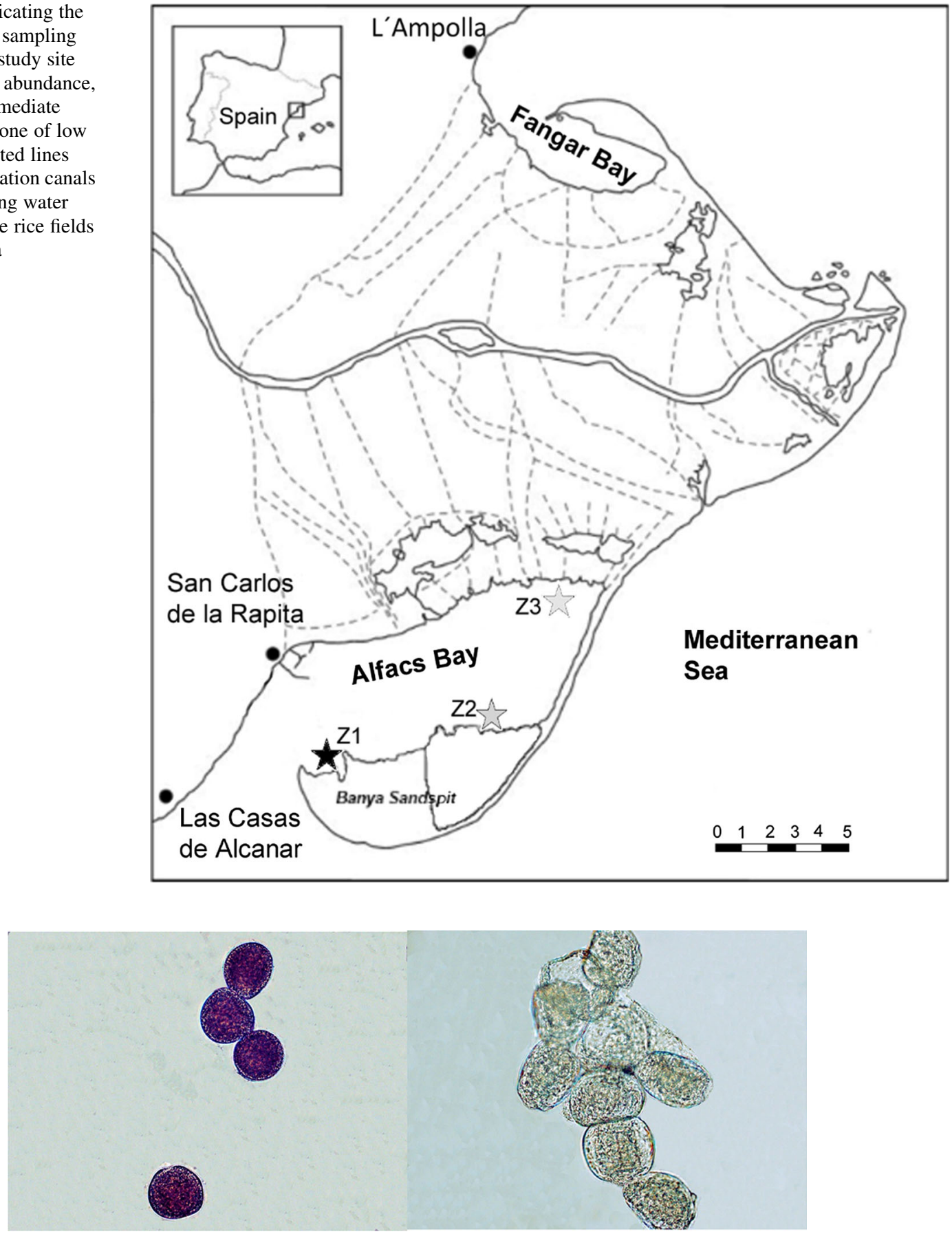

Fig. 3 Exemplars of $P$. nobilis eggs (left) and larvae (right) produced in the laboratory using artificial gamete induction/fertilization

by spectrophotometry to evaluate purity and concentration. Seawater samples were filtered using $10 \mu \mathrm{m}$ mesh nylon filters and the filtrate treated the same as eggs and larvae samples using the same protocol.
DNA concentrations of all tissue samples were normalized to $100 \mathrm{ng} / \mu \mathrm{l}$, based upon the values obtained by spectrophotometry, prior to use for PCR. For all other sample types (eggs, larvae, or seawater) 


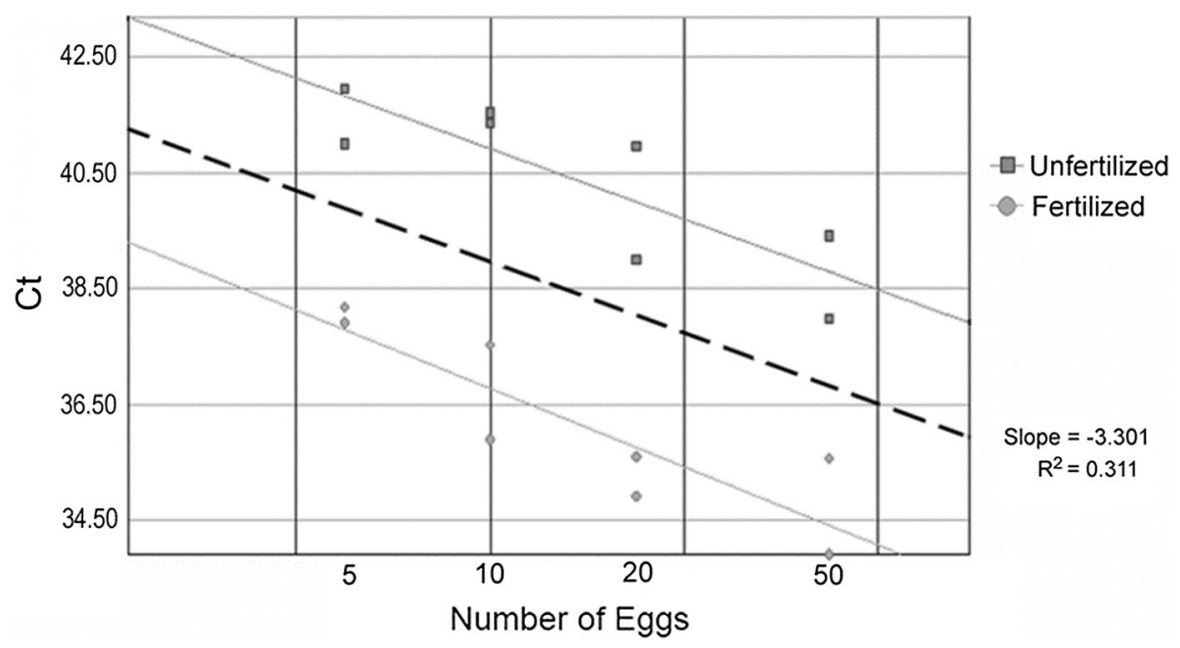

Fig. 4 Calibration curve demonstrating distinct results for fertilized and unfertilized eggs of $P$. nobilis. Squares $=$ fertilized egg samples. Circles = unfertilized egg samples. Linear regression of results for fertilized or unfertilized eggs (solid

$1 \mu \mathrm{l}$ of DNA, from a total eluate of $30 \mu \mathrm{l}$, was added directly to the reaction, or (see below) diluted 1:10.

Primers used for amplification of the ribosomal DNA internal transcribed spacer region (ITS-1, 5.8S, ITS-2) were DinoE 5' CCKSTTCAYTCGCCRTTAC $3^{\prime}$ and 18dKA 5' CACACCGCCCGTCGCTACTACC $3^{\prime}$ (Andree et al., 2011) and were included at a final concentration of $0.6 \mu \mathrm{M}$ each. Additionally, each 25 $\mu \mathrm{l}$ reaction also contained $0.5 \mathrm{U}$ Taq DNA polymerase (Ref.\# 10342-020 Invitrogen, Carlsbad, CA, USA), $800 \mu \mathrm{M}$ dNTPs, $2 \mathrm{mM} \mathrm{MgCl} 2$, and 5\% DMSO. The thermal cycler program used was 40 cycles of $95^{\circ} \mathrm{C}$ for $1 \mathrm{~min}, 55^{\circ} \mathrm{C}$ for $1 \mathrm{~min}$, and $72^{\circ} \mathrm{C}$ for $1.5 \mathrm{~min}$, preceded by $5 \mathrm{~min}$ at $95^{\circ} \mathrm{C}$, and followed by $10 \mathrm{~min}$ at $72^{\circ} \mathrm{C}$. The resulting genomic fragment was approximately $1200 \mathrm{bp}$. Each PCR product was purified using the Qiagen PCR Purification Kit (Qiagen, Valencia, CA, USA), then sent to a private company for bidirectional sequencing using the same primers as those in the original amplification (Sistemas Genomicos, Valencia, Spain). The resulting sequence data were edited and trimmed using BioEdit ver 7.0.5.2 (Hall, 1999) to remove terminal primer sequence artifacts and cleaned of any aberrant basecalling before aligning the forward and reverse reads to construct a consensus sequence representative of the specimens analyzed. The sequence was then subjected to analysis using BLAST to confirm the identity of the sequence obtained. Further, the BLAST results served to lines) indicates efficiencies of amplification of 99.8 and $98.6 \%$, respectively. Efficiency of assay calculated from the slope of the linear regression obtained from all egg samples was $100.9 \%$ (dotted line)

identify what species might have sequences already described in the GenBank database that are similar. The $P$. nobilis sequence was used for designing the species-specific primers that avoided the repeat regions to be applied in the qPCR assay. The primer pair Pin ITSF3 $5^{\prime}$ GTACCTGTGCCGAGTTCTCTC G $3^{\prime}$ and Pin ITSR2 5' CGCCGTTGGATGAAACCG TACG $3^{\prime}$ produced a 180 bp product, and this pair was chosen for use in assay optimization. The primer BLAST application (within GenBank NCBI) was used to test in silico the specificity of the primers and validate the absence of any other priming site within sequences currently in the NCBI database. After testing various annealing temperatures, the final qPCR program consisted of 45 cycles of $95^{\circ} \mathrm{C}$ for $20 \mathrm{~s}, 66^{\circ} \mathrm{C}$ for $30 \mathrm{~s}$, preceded by $5 \mathrm{~min}$ at $95^{\circ} \mathrm{C}$, and followed by a dissociation stage for determining the melt curve. All reactions contained $1 \times$ SYBR Green mix (Ref\# 4364344, Thermo Fisher Scientific, USA) and $0.5 \mu \mathrm{M}$ of each primer. Samples were analyzed in triplicate, and each plate (96 wells) contained negative and positive controls of genomic DNA from adult tissues to confirm validity of the reactions. For all positive results, comparison of melt curves of unknowns from all collection sites (3 subsites within Alfacs Bay, as well as Las Casas de Alcanar, and southeast of France) was made to melt curves of our known positive controls for confirmation of sequence identity. 
Calibration curves, specificity, and assay optimization

To confirm the specificity of the assay, primers were tested using $50 \mathrm{ng}$ of genomic DNA from the three most abundant commercially produced shellfish species: Crassostrea gigas, Cerastoderma edule, and Mytilus galloprovincialis. Further, the species-specific qPCR was tested on different numbers of eggs and larvae produced by captive spawning (as mentioned above) from individuals located in the Southeast of France and preserved in 70\% ethanol (Trigos et al., 2017). Specific numbers of fertilized and unfertilized eggs, and larvae from these lab samples $(n=5,10,20$ and 50; with two replicates of each), were used for the purpose of establishing a correlation between the $C_{\mathrm{t}}$ values obtained and the number of individuals (fertilized/unfertilized eggs or larvae), i.e.,- a calibration curve. DNA extractions were performed as before with the Qiagen Blood and Tissue Kit, but with the additional step of bead-beating using a BeadBeater-8 (BioSpec Products, Bartlesville, OK, USA). Further, genomic DNA obtained from adult tissues was also tested for calibration and used to evaluate the overall efficiency of the assay. Additionally, a subset of DNA extracts was serially diluted (1:10, 1:20, 1:50, 1:100) to remove/dilute potential PCR inhibitors that may have originated in either the egg matrix or seawater as seen previously (Andree et al., 2011). All DNA extracts were eluted in a final volume of $30 \mu$ l. Linear regression of the calibration curve established a slope that was used for the calculation of amplification efficiency $(E \%)$ following the equation: $E \%=1 \alpha^{-1 /}$ slope) -1 .

\section{Results}

Multiple repeat regions (short poly-A, poly-G, and poly-C stretches) were detected during sequence analysis of the intergenic transcribed spacer (ITS) rDNA sequences. These were problematic for sequencing and establishment of correct consensus sequences. Aside from the repeat regions, the remaining sequence fragments from all 30 isolates provided a clear consensus sequence. The two longest unambiguous sequences obtained have been uploaded to GenBank under accession numbers KX101234 and KX101235. Of the 447 bivalve mollusk ITS ribosomal
DNA sequences currently in GenBank, results from BLAST analysis found only one species (other than $P$. nobilis), Perna perna that was a near match with a similarity index of $96.4 \%$. No primer binding of the designed primers to the Perna perna sequence was evident in silico. Testing the different primer sets for $P$. nobilis demonstrated that each of the primer pairs tested had distinct melt curves (data not shown). The primer pair chosen amplified its respective target more robustly as compared to the other primer sets, as evidenced by the lower $\mathrm{Ct}$ value obtained when using the same quantity of DNA. Further, no amplification was seen when using genomic DNA from $C$. gigas, $C$. edule, or M. galloprovincialis, confirming in part, the specificity of the assay. Optimization of the assay using the DNA from adult tissues established an $E \%=$ 99.8\% $\left(R^{2}=0.997\right)$. This was similar for fertilized $\left(97.6 \% ; R^{2}=0.89\right)$ and unfertilized $\left(99.8 \% ; R^{2}=0.98\right)$ eggs, although the $y$ intercepts were 50.33 and 54.23 , respectively. The slope obtained when all egg samples were included indi-cated efficiency of $100.9 \%$ (Fig. 4).

Results of the calibration curve using larvae samples gave erratic results with no correspondence between extracted DNA and specific numbers of larvae per sample. We did obtain a standard curve using larvae, however the slope obtained was -3.73 indicating a $E \%=85.4 \%$. Another assay was conducted using seven replicates of only one larvae. The mean of the $C_{\mathrm{t}}$ values from these was 36.9. Using the standard curve for diploid eggs, a $C_{\mathrm{t}}$ of 36.9 is approximately 17,844 diploid cells. This value was used to correct for all the other calculations made from larvae isolated from field samples. Thus, the $C_{\mathrm{t}}$ value obtained from one larva was used to normalize the quantity of $P$. nobilis larvae within plankton net field samples, giving a range from 0.2 to 32.4 (i.e., up to 8.6 larvae $\cdot \mathrm{m}^{-3}$ ).

Field samples of $500 \mathrm{ml}$ water collected in Alfacs Bay were all negative. Tests performed to establish possible losses of eggs and larvae during the filtration process were evaluated using pseudo-field samples (filtered seawater samples spiked with either ten eggs or one egg) and showed that samples with one egg in more than $50 \mathrm{ml}$ were not consistently positive.

Further, although DNA was obtained from both field samples and preserved lab-cultured samples, there were some doubts about possible PCR inhibition since the expected amplification at $C_{\mathrm{t}}$ values lower 
than 25 was not observed. Testing by qPCR of some samples serially diluted $(1: 10,1: 20,1: 50,1: 100)$ was performed to eliminate potential inhibitors, but the expected reduction in $\mathrm{Ct}$ values (an indication of suppression of inhibition) was not observed. Yet, we continued using 1:10 dilutions in order to increase the quantity of sample available for experimentation.

Larvae from the plankton net samples collected manually using a micro-spoon under a dissecting microscope were used in a pool as DNA extraction material. From among these samples, several (15/62) were identified as containing $P$. nobilis (Table 1). The number of positives increased slightly from June-July to August-September. From the total number of positive samples, the mean $C_{\mathrm{t}}$ value was 36.41 .

\section{Discussion}

The present study constitutes the first approach conducted for quantifying the abundance of $P$. nobilis larvae in the water column, and proved to be effective in detecting $P$. nobilis DNA from larvae obtained from field samples. The assay did not amplify DNA of other mollusk and non-target bivalve species as confirmed by comparison to the melt curve profiles from known positive samples. Further, the few positives detected among the larvae collected from plankton net samples, (as well as the low number of "hits", seen by BLAST analysis) strongly suggest this assay has a high specificity. The assay performed as expected with $P$. nobilis DNA from three distinct populations (Alfacs Bay, Las Casas de Alcanar, and Southeast of France), supporting that it has broad applicability for similar quantitative assessments in other Mediterranean regions. We collected samples from all the local Pinna shellfish beds of which we were aware for evaluating the genetic diversity of the local populations. This was to ensure that the assay should be productive for this species with no "cross reactivity" with related shellfish. The conserved nature of the ribosomal DNA regions where the diagnostic primers bind provides support for this. Whether the sequence data obtained represent a consensus for all populations across the Mediterranean requires further sequence data, sampling, and utilization of this test for assessment. However, the results are suggestively robust considering some of the tested samples are from as far away as France. Additionally, Wesselmann et al. (2018) demonstrated using microsatellite markers that populations of $P$. nobilis from across the Mediterranean have low inter-population diversity, while genetically having high connectivity, which suggests this marker will be useful for areas outside the Ebro Delta and into the Eastern Mediterranean.

The documented ITS rDNA region used in this qPCR assay development was rich in homopolymer and repeat sequences (areas under less selective genetic pressure) that likely caused the difficulty in getting equivalent amplification from some primer sets initially tested despite their being designed to avoid these regions. Studies of genetic diversity may find this region useful since regions rich in repeat sequences, such as those found here, frequently expand or contract during the course of evolution (Read et al., 2004); this being the basis for microsatellite analysis. Previous phylogenetic studies related to this genus have used more standard genetic markers such as cytochrome oxidase (Sanna et al., 2013, 2014), microsatellite DNA (Gonzalez-Wanguemert et al., 2015; Wesselmann et al., 2018), or nuclear and mitochondrial ribosomal genes (Lemer et al., 2014). In the case of the latter study, cryptic species were identified within the family Pinnidae. Hence, utilizing the ITS region of the rDNA cistron might reveal still more genetic diversity, adding new insights into variability among different populations.

Only few $P$. nobilis larvae were present during the expected summer spawning period (Kersting \& Garcia-March, 2007). All samples displayed high Ct values (between 31.9 and 39.6 with mean value of 36.41 ), indicative of very low abundance of planktonic stages, yet still supporting the efficiency of the speciesspecific qPCR as a detection tool. The highest number of larvae visually observed among the sam-ples that tested positive by qPCR was 3237 collected from zone 3 of Alfacs Bay on Oct. 1. Given the $\mathrm{Ct}$ value obtained 37.49 , it is possible that only one larvae among those could be considered as being $P$. nobilis. If the recruitment bottleneck resided with ecological processes occurring in the benthos, then a paucity of developmental stages would be expected in the substrata while there would be an abundance of planktonic stages in the water column. However, the low abundance of planktonic stages observed suggests some local processes are affecting the water column, rather than the benthos, and could be interfering with the production of viable larvae. Although during the 
Table 1 Summary of qPCR results from larvae collected between mid-July and September

\begin{tabular}{|c|c|c|c|c|c|c|c|}
\hline \multirow[t]{2}{*}{ Date } & \multicolumn{4}{|c|}{ Larval counts from plankton net samples } & \multicolumn{3}{|c|}{ qPCR } \\
\hline & Site & Replicate & Subsample & Total $N$ & \pm & Mean $C_{\mathrm{t}}$ & \# Larvae* \\
\hline \multirow[t]{9}{*}{ 07/15/2016 } & Zone 1 & $\mathrm{R} 1$ & 174 & & - & & \\
\hline & & $\mathrm{R} 2$ & 129 & & - & & \\
\hline & & $\mathrm{R} 3$ & 141 & & - & & \\
\hline & Zone 2 & $\mathrm{R} 1$ & 0 & & - & & \\
\hline & & $\mathrm{R} 2$ & 3 & & + & 38.39 & 0.4 \\
\hline & & R3 & 154 & & - & & \\
\hline & Zone 3 & $\mathrm{R} 1$ & 14 & & + & 38.04 & 0.5 \\
\hline & & $\mathrm{R} 2$ & 11 & & + & 36.19 & 1.6 \\
\hline & & R3 & 102 & & - & & \\
\hline \multirow[t]{9}{*}{ 08/01/2016 } & Zone 1 & R1 & 102 & & - & & \\
\hline & & $\mathrm{R} 2$ & 126 & & - & & \\
\hline & & R3 & 99 & & - & & \\
\hline & Zone 2 & $\mathrm{R} 1$ & 50 & & - & & \\
\hline & & $\mathrm{R} 2$ & 49 & & - & & \\
\hline & & R3 & 104 & & - & & \\
\hline & Zone 3 & $\mathrm{R} 1$ & 156 & & - & & \\
\hline & & $\mathrm{R} 2$ & 365 & & - & & \\
\hline & & R3 & 446 & 1279 & - & & \\
\hline \multirow[t]{9}{*}{ 08/15/2016 } & Zone 1 & $\mathrm{R} 1$ & 30 & & + & 35.85 & 2.1 \\
\hline & & $\mathrm{R} 2$ & 37 & & + & 39.57 & 0.2 \\
\hline & & R3 & 52 & & + & 38.59 & 0.3 \\
\hline & Zone 2 & $\mathrm{R} 1$ & 262 & 1368 & - & & \\
\hline & & $\mathrm{R} 2$ & 141 & 566 & - & & \\
\hline & & R3 & 116 & 233 & - & & \\
\hline & Zone 3 & $\mathrm{R} 1$ & 750 & 2149 & - & & \\
\hline & & $\mathrm{R} 2$ & 851 & 3143 & - & & \\
\hline & & R3 & 472 & 1905 & - & & \\
\hline \multirow[t]{9}{*}{ 09/01/2016 } & Zone 1 & R1 & 22 & & + & 36.11 & 1.7 \\
\hline & & $\mathrm{R} 2$ & & & - & & \\
\hline & & $\mathrm{R} 3$ & & & - & & \\
\hline & Zone 2 & $\mathrm{R} 1$ & 33 & & - & & \\
\hline & & $\mathrm{R} 2$ & 29 & & + & 37.32 & 0.8 \\
\hline & & R3 & 56 & & + & 31.86 & 32.4 \\
\hline & Zone 3 & $\mathrm{R} 1$ & 30 & & - & & \\
\hline & & $\mathrm{R} 2$ & 302 & & - & & \\
\hline & & R3 & 39 & & + & 37.76 & 0.6 \\
\hline \multirow[t]{9}{*}{ 09/15/2016 } & Zone 1 & $\mathrm{R} 1$ & 54 & & + & 32.06 & 28.1 \\
\hline & & $\mathrm{R} 2$ & 116 & & - & & \\
\hline & & R3 & 271 & 797 & - & & \\
\hline & Zone 2 & $\mathrm{R} 1$ & 175 & & - & & \\
\hline & & $\mathrm{R} 2$ & 185 & & - & & \\
\hline & & R3 & 262 & & - & & \\
\hline & Zone 3 & $\mathrm{R} 1$ & 306 & 686 & - & & \\
\hline & & $\mathrm{R} 2$ & 363 & 580 & - & & \\
\hline & & R3 & 526 & 15,272 & - & & \\
\hline
\end{tabular}


Table 1 continued

\begin{tabular}{|c|c|c|c|c|c|c|c|}
\hline \multirow[t]{2}{*}{ Date } & \multicolumn{4}{|c|}{ Larval counts from plankton net samples } & \multicolumn{3}{|c|}{ qPCR } \\
\hline & Site & Replicate & Subsample & Total $N$ & \pm & Mean $C_{\mathrm{t}}$ & \# Larvae* \\
\hline \multirow[t]{9}{*}{$10 / 01 / 2016$} & Zone 1 & $\mathrm{R} 1$ & 118 & & + & 35.02 & 3.6 \\
\hline & & $\mathrm{R} 2$ & 321 & 924 & - & & \\
\hline & & $\mathrm{R} 3$ & 250 & 3237 & + & 37.49 & 8.6 \\
\hline & Zone 2 & $\mathrm{R} 1$ & 11 & & + & 35.50 & 2.6 \\
\hline & & $\mathrm{R} 2$ & 68 & & - & & \\
\hline & & R3 & 53 & & - & & \\
\hline & Zone 3 & $\mathrm{R} 1$ & 25 & & - & & \\
\hline & & $\mathrm{R} 2$ & 40 & & + & 36.39 & 1.4 \\
\hline & & R3 & 20 & & - & & \\
\hline
\end{tabular}

The number of larvae shown in "Subsample" is the number of larvae in the extracted DNA samples tested. "Total N" is the number extrapolated from counting the subsample. All positives recorded had high Ct values between 31.9 and 39.6 (mean = 36.41). Larvae number are extrapolated from the calibration curve obtained from diploid eggs and the mean value of 7 replicates for amplification of one larvae: $36.9=17,844$ diploid cells

study we chose three sites where population densities of $P$. nobilis were significantly different (Prado et al., 2014), the low Ct values observed prevented determination of a clear relationship between each zone and their larval abundance. Among potential causes of larval supply limitation at the broad spatial scale of the Alfacs Bay, endocrine disrupting organophosphates discharged from rice fields during the summer period might be causing alterations in the proper functional development of the reproductive system (Terrado et al., 2007; Frye et al., 2012). Several such com-pounds have been identified in environmental com-partments and wildlife of the Ebro Delta, and reproductive impacts on water fowl (Mañosa et al., 2001), as well as alterations of acetylcholinesterase (AChE) activity in Mytilus galloprovincialis (Escartin \& Porte, 1997) have been reported. In addition, lower salinity in Northern areas of the Bay due to persistent discharge of agricultural water also affects $P$. nobilis reproduction and ultimately may account for differences in adult abundances among the three zones (Prado et al., 2014).

Due to funding limits, samples were collected only during the expected spawning season from July to October. While this is not a full year of sampling it should be regarded as significant considering that material was collected from three different sites within Alfacs Bay, and in triplicate subsites at each site. Those samples that tested positive were few, and simply a matter of the circumstances that point towards the very reason we performed this study. In all, only 15 samples were identified as containing $P$. nobilis DNA from mid-July to the beginning of October 2016. However, there were $30 \%$ more positive samples in September/October $(n=9)$ than in July/August $(n=6)$. In addition, the mean $C_{\mathrm{t}}$ value of larval samples from Sept-Oct was ca. 2.7 times lower than in the July-Aug period, suggesting an increase in larval abundance, or in size of individual larvae. Yet, according to results using calibration curves, there were few $P$. nobilis in the water column (an average of $12.4 \mathrm{~m}^{-3}$ ), which indicates very low availability of larvae. Although the number of $P$. nobilis larvae has never been quantified in previous studies and it is impossible to establish common abundance ranges, the very low occurrence of juve-niles in the area (Prado et al., 2014) suggests that they are abnormally low. This pattern is also confirmed by local recruitment data for 2016, which registered a total absence of individuals (Prado et al., in prep) whereas in other areas nearby such as the Columbretes Islands, located only $100 \mathrm{~km}$ south from Alfacs Bay, recruitment has been clearly demonstrated (Kersting \& García-March, 2007). In other species of bivalves such as the brown mussel Perna perna and the clam Ruditapes decussatus, larval peaks of hundreds to thousands of individuals per $\mathrm{m}^{-3}$ have been reported and result in high rates of recruitment (Chi'charo \& Chícharo, 2001; Porri et al., 2006). 
Since the number of $P$. nobilis larvae in all samples analyzed was small (mean $C_{\mathrm{t}}$ value for all positives of 36.41 ), most of the observed larvae were likely from other locally abundant species such as oysters, mussels, clams, and/or cockles. For instance, in the case of the sample with the highest recorded abundance of larvae $(15,272)$, collected on Sept. 15th, no P. nobilis DNA was detected. At present, the identification of morphometric characters requires extreme expertise and specialization in ontogenetic bivalve development (e.g., Malchus \& Sartori, 2013), so this information was not collected in this work. Yet, future multidisciplinary studies may also include this type of analysis prior to DNA extraction and qPCR.

In the use of $500 \mathrm{ml}$ water samples, none tested positive. Although when using the plankton net protocol for sampling, the estimated volume of water filtered (ca. $3.77 \mathrm{~m}^{3}$ ) was an increase of over 7000fold. Yet, negative results for seawater samples of 500 $\mathrm{ml}$ are coherent with low $C_{\mathrm{t}}$ values and scarce $P$. nobilis-positive results from tests performed with collected larvae stages. This was surprising given that the bay harbors the second largest population of this species in the Mediterranean (Prado et al., 2014). A possible reason for the reduced number of positive results could be dilution of planktonic stages of the target species within the large dimensions of Alfacs Bay (ca. $49 \mathrm{Km}^{2}$ and average depth of $3.13 \mathrm{~m}$ ). This dilution effect due to the large volume of the bay might be further enhanced by the continual renewal rate of the bay's water, even though tidal changes are low in the Mediterranean. This is in contrast to similar works in which water from ponds with little or no water renewal were analyzed by qPCR for the presence of frog (Rana catesbeiana) DNA (Ficetola et al., 2008) where sloughed epithelial cells contained in mucus from the frog's skin might accumulate in the absence of continual water renewal. Further, in this study when testing "pseudo-field samples," only 15 and $50 \mathrm{ml}$ volumes containing one egg of $P$. nobilis consistently tested as positive, whereas $500 \mathrm{ml}$ volumes used were negative. However, all volumes were positive when ten eggs were added. This hints at some possible underestimation of DNA contents in field water samples of $500 \mathrm{ml}$; however, this volume was still preferred to maximize the potential of capturing multiple planktonic stages. Additional factors that may have contributed to the absence of positives from $500 \mathrm{ml}$ water samples include low rate of adult mortality (a cause of release of necrotic tissue and cells from moribund animals), reduced spawning and larval abundance, or any combination of these factors.

Although the bay is also the site of intensive shellfish culture (C. gigas, C. edule, and Mytilus galloprovincialis) as well as artisanal harvest of other natural shellfish populations (Cerastoderma sp., carpet shell clam Ruditapes decussatus and the razor clam Solen marginatus), no false positives were detected, as would be evident from the melt curve profiles.

Calibration curves of fertilized and unfertilized eggs, and adult tissue (data not shown) showed very similar slopes but differed in their $y$-intercept, an indication of their cells being haploid or diploid. There was significant deviation among replicates that might have been due to artifacts such as free DNA in the aqueous fraction that was transferred with the eggs into the subsample tubes, and/or free DNA adherent to the surface of the eggs via DNA-binding cell surface receptors such as nucleolin (Bennett et al., 1985; Chen et al., 2008). Moreover, the eggs and larvae used were from experimental captive spawning in which all of the larvae produced eventually died. Therefore, it can be presumed that the larvae used may not have been in optimal condition, and if in a moribund state at the time of fixation, in which cells were undergoing apoptosis, the quality of the genetic material obtained may not have been consistent among animals within a sample, or cells within an individual animal. Additionally, ribosomal DNA copy number is likely to increase post-fertilization by regulatory mechanisms that implicate genes like fobl or similar (Johzuka \& Horiuchi, 2002), that would also contribute to variation between individual eggs and egg groups. Given that the absence or low rates of fertilization might be indicative of some type of infertility among adult individuals (e.g., Lewis \& Ford, 2012), this ability to differentiate between fertilized and unfertilized eggs might be a useful tool in future studies aimed at establishing the causes of larval and recruitment failure.

To conclude, the development of analytical tools such as qPCR to assess the availability of planktonic stages of $P$. nobilis and the ability to differentiate between fertilized and non-fertilized eggs should help to address possible bottlenecks related to gamete viability, clarify concerns of agro-chemical impacts and species-specific sensitivity, and determine the influence of large-scale environmental factors on the 
larval recruitment of this species. Future research efforts need to focus on using qPCR tools to monitor larval abundances in Alfacs Bay and in other Mediterranean areas, in order to address some of these questions to aid in understanding better how to improve management of wild stocks of this emblematic Mediterranean bivalve.

Acknowledgements The authors wish to thank the Zoo Barcelona Foundation for an Antoni Jonch Grant 2015, which provided the economic support necessary to accomplish this work. Authors are very grateful to Dr. Miguel Alonso GarcíaAmilivia for the construction of the zooplankton micro-spoon for the collection of $P$. nobilis eggs and larvae. Also, authors would like to thank Pep Cabanes, Lluis Jornet, and David Mateu for technical assistance during fieldwork sampling in Alfacs Bay.

\section{Compliance with ethical standards}

Conflict of interest The authors declare that they have no conflict of interest.

\section{References}

Andree, K. B., S. Quijano-Scheggia, M. Fernández, L. M. Elandaloussi, E. Garcés, J. Camp \& J. Diogene, 2011. Quantitative PCR coupled with melt curve analysis for detection of selected Pseudo-nitzschia spp. (Bacillariophyceae) from the northwestern Mediterranean Sea. Applied and Environmental Microbiology 77: 1651-1659.

Bennett, R. M., G. T. Gabor \& M. M. Merritt, 1985. DNA binding to human leukocytes. Evidence for a receptormediated association, internalization, and degradation of DNA. Journal of Clinical Investigation 76: 2182-2190.

Butler, A., N. Vicentem \& B. De Gaulejac, 1993. Ecology of de pterioid bivalves Pinna bicolor Gmelin and P. nobilis L. Marine Life 3: 37-45.

Centoducati, G., E. Tarsitano, A. Bottalico, M. Marvulli, O. R. Lai \& G. Crescenzo, 2007. Monitoring of the endangered Pinna nobilis Linné, 1758 in the Mar Grande of Taranto (Ionian Sea, Italy). Environtal Monitoring and Assessment 131: 339-347.

Chen, X., D. M. Kube, M. J. Cooper \& P. B. Davis, 2008. Cell surface nucleolin serves as receptor for DNA nanoparticles composed of pegylated polylysine and DNA. American Society of Gene Therapy 16: 333-342.

Chícharo, L. \& M. A. Chícharo, 2001. A juvenile recruitment prediction model for Ruditapes decussatus (L.) (Bivalvia: Mollusca). Fisheries Research 53: 219-233.

Coppa, S., G. A. de Lucia, P. Magni, P. Domenici, F. Antognarelli, A. Satta \& A. Cucco, 2013. The effect of hydrodynamics on shell orientation and population density of Pinna nobilis in the Gulf of Oristano (Sardinia, Italy). Journal of Sea Research 76: 201-210.

Darriba, S., 2017. First haplosporidan parasite reported infecting a member of the Superfamily Pinnoidea (Pinna nobilis) during a mortality event in Alicante (Spain, Western Mediterranean). Journal of Invertebrate Pathology 148: 14-19.

De Gaulejac, B. \& N. Vicente, 1990. Ecologie de Pinna nobilis (L.) mollusque bivalve sur les côtes de Corse. Essais de transplantation et expériences en milieu contrôlé. Haliotis 10: 83-100.

Dejean, T., A. Valentini, A. Duparc, S. Pellier-Cuit, F. Pompanon, P. Taberlet \& C. Miaud, 2011. Persistence of environmental DNA in freshwater ecosystems. PLoS ONE 6: e23398.

Ebert, T. A., 1983. Recruitment in echinoderms. Echinoderm Studies 1: 169-203.

Endo, N., K. Sato \& Y. Nogata, 2009. Molecular based method for the detection and quantification of larvae of the golden mussel Limnoperna fortunei using real-time PCR. Plankton Benthos Research 4: 125-128.

Endo, N., K. Matsumura, E. Yoshimura, Y. Odaka \& Y. Nogata, 2010. Species-specific detection and quantification of common barnacle larvae from the Japanese coast using real time PCR. Biofouling 26: 901-911.

Escartin, E. \& C. Porte, 1997. The use of cholinesterase and carboxylesterase activities from Mytilus galloprovincialis in pollution monitoring. Environmental Toxicology and Chemistry 16: 2090-2095.

Ficetola, G. F., C. Miaud, F. Pompanon \& P. Taberlet, 2008. Species detection using environmental DNA from water samples. Biology Letters 4: 423-425.

Frischer, M. E., A. S. Hansen, J. A. Wyllie, J. Wimbush, J. Murray \& S. A. Nierzwicki- Bauer, 2002. Specific amplification of the $18 \mathrm{~S}$ rRNA gene as a method to detect zebra mussel (Dreissena polymorpha) larvae in plankton samples. Hydrobiologia 487: 33-44.

Frye, C., E. Bo, L. Calzà, F. Dessì-Fulgheri, M. Fernández, L. Fusani, O. Kah, M. Kajta, Y. Le Page, H. B. Patisaul, A. Venerosi, A. K. Wojtowicz \& G. C. Panzica, 2012. Endocrine disruptors: a review of some sources, effects, and mechanisms of action on behavior and endocrine systems. Journal of Neuroendocrinology 24: 144-159.

García-March, J. R. \& D. K. Kersting, 2006. Preliminary data on the distribution and density of Pinna nobilis and Pinna rudis in the Columbretes Islands Marine Reserve (Western Mediterranean, Spain). Organisms Diversity and Evolution 6: 06-16.

Gonzalez-Wanguemert, M., J. Costa, L. Basso, C. M. Duarte, E. A. Serrao \& I. Hendriks, 2015. Highly polymorphic microsatellite markers for the Mediterranean endemic fan mussel Pinna nobilis. Mediterranean Marine Science 16: 31-35.

Guallart, J., \& J. Templado, 2012. Pinna nobilis. In: VV. AA., Bases ecológicas preliminares para la conservación de las especies de interés comunitario en España: Invertebrados. Ministerio de Agricultura, Alimentación y Medio Ambiente, Madrid: 81.

Hall, T. A., 1999. BioEdit: a user-friendly biological sequence alignment editor and analysis program for Windows 95/98/ NT. Nucleic Acids Symposium Series 41: 95-98.

Johzuka, K. \& T. Horiuchi, 2002. Replication fork block protein, Fob1, acts as an rDNA region specific recombinator in S. cerevisiae. Genes to Cells 7: 99-113. 
Katsanevakis, S., 2007. Growth and mortality rates of the fan mussel Pinna nobilis in Lake Vouliagmeni (Korinthiakos Gulf, Greece): a generalized additive modelling approach. Marine Biology 152: 1319-1331.

Kersting, D. K., \& J. R. García-March, 2007. Preliminary data on Pinna nobilis larval recruitment using mesh collectors in Columbretes Islands Marine Reserve, NW Mediterranean. In: European Symposium on Marine Protected Areas. Murcia, 25th-28th September 2007.

Lemer, S., B. Buge, A. Bemis \& G. Giribet, 2014. First molecular phylogeny of the circumtropical bivalve family Pinnidae (Mollusca, Bivalvia): evidence for high levels of cryptic species diversity. Mol Phylo Evol 75: 11-23.

Lewis, C. \& A. T. Ford, 2012. Infertility in male aquatic invertebrates: a review. Aquatic Toxicology 120: 79-89.

Malchus, N. \& A. F. Sartori, 2013. Part N, Revised, Volume 1, Chapter 4: the early shell: ontogeny, features, and evolution. Treatise Online 61: 1-114.

Mañosa, S., R. Mateo \& R. Guitart, 2001. A review of the effects of agricultural and industrial contamination on the Ebro Delta Biota and wildlife. Environmental Monitoring and Assessment. 71: 187-205.

Marbà, N., C. M. Duarte, J. Cebrián, M. E. Gallegos, B. Olesen \& K. Sand-Jensen, 1996. Growth and population dynamics of Posidonia oceanica on the Spanish Mediterranean coast: elucidating seagrass decline. Marine Ecology Progress Series 137: 203-213.

Porri, F., C. D. McQuaid \& S. Radloff, 2006. Spatio-temporal variability of larval abundance and settlement of Perna perna: differential delivery of mussels. Marine Ecology Progress Series 315: 141-150.

Prado, P., F. Tomas, S. Pinna, S. Farina, G. Roca, G. Ceccherelli, J. Romero \& T. Alcoverro, 2012. Habitat and scale shape the demographic fate of the keystone sea urchin Paracentrotus lividus in mediterranean macrophyte communities. PloS ONE 7: e35170.

Prado, P., N. Caiola \& C. Ibáñez, 2014. Habitat use by a large population of Pinna nobilis in shallow waters. Scientia Marina 78: 555-565.

Read, L. R., S. J. Raynard, A. Rukść \& M. D. Baker, 2004. Gene repeat expansion and contraction by spontaneous intrachromosomal homologous recombination in mammalian cells. Nucleic Acids Research 32: 1184-1196.

Robert, R. \& A. Gerard, 1999. Bivalve hatchery technology: the current situation for the Pacific oyster Crassostrea gigas and the scallop Pecten maximus in France. Aquatic Living Resources 12(2): 121-130.

Sanna, D., P. Cossu, G. L. Dedola, F. Scarpa, F. Maltagliati, A. Castelli, P. Franzoi, T. Lai, B. Cristo, M. Curini-Galletti, P. Francalacci \& M. Casu, 2013. Mitochondrial DNA reveals genetic structuring of Pinna nobilis across the Mediterranean Sea. PloS ONE 8(6): e67372.
Sanna, D., G. L. Dedola, F. Scarpa, T. Lai, P. Cossu, M. CuriniGalletti, P. Francalacci \& M. Casu, 2014. New mitochondrial and nuclear primers for the Mediterranean marine bivalve Pinna nobilis. Mediterranean Marine Science 15(2): 416-422.

Siletic, T. \& M. Peharda, 2003. Population study of the fan shell Pinna nobilis in Malo and Veliko Jezero of the Mljet National Park (Adriatic Sea). Scientia Marina 67: 91-98.

Terrado, M., M. Kuster, D. Raldúa, M. Lopez de Alda, D. Barceló \& R. Tauler, 2007. Use of chemometric and geostatistical methods to evaluate pesticide pollution in the irrigation and drainage channels of the Ebro river delta during the rice-growing season. Anal Bioanal Chem. 387: 1479-1488.

Trigos, S., 2017. Estudio de la ecofisiología y ensayo de cultivo de la nacra Pinna nobilis Linnaeus, 1758. PhD Thesis, Facultad de Veterinaria y Ciencias Experimentales, Universidad Católica de Valencia.

Trigos, S., N. Vicente, P. Prado \& F. J. Espinós, 2017. Adult spawning and early larval development of the endangered bivalve Pinna nobilis. Aquaculture 483: 102-110.

Vadopalas, B., J. V. Bouma, C. R. Jackels \& C. S. Friedman, 2006. Application of real-time PCR for simultaneous identification and quantification of larval abalone. Journal of Experimental Marine Biology and Ecology 334: 219-228.

Wesselmann, M., M. González-Wangüemert, E. A. Serrão, A. H. Engelen, L. Renault, J. R. García-March, C. M. Duarte \& Iris. E. Hendriks, 2018. Genetic and oceanographic tools reveal high population connectivity and diversity in the endangered pen shell Pinna nobilis. Scientific Reports 8(4770): 1-11.

Wilcox, T. M., K. S. McKelvey, M. K. Young, S. F. Jane, W. H. Lowe, A. R. Whiteley \& M. K. Schwartz, 2013. Robust detection of rare species using environmental DNA: the importance of primer specificity. PLoS ONE 8: e59520.

Wren, J. D., E. Forgacs, J. W. Fondon III, A. Pertsemlidis, S. Y. Cheng, T. Gallardo, R. S. Williams, R. V. Shohet, J. D. Minna \& H. R. Garner, 2000. Repeat polymorphisms within gene regions: phenotypic and evolutionary implications. American Journal of Human Genetics 67: 345-356.

Zakhama-Sraieb, R., Y. R. Sghaier, A. Omrane \& F. CharfiCheikhrouha, 2011. Density and population structure of Pinna nobilis (Mollusca, Bivalvia) in the Ghar El Melh lagoon (N-E Tunisia). Bulletin de l'Institut National des Sciences et Technologies de la Mer de Salammbô 38: 65-71.

Zavodnik, D., M. Brenko \& M. Legac, 1991. Synopsis on the fan shell Pinna nobilis L. in the eastern Adriatic Sea. In Boudouresque, C. F., M. Avon \& V. Gravez (eds), Les Espèces Marines à Protéger en Méditerranée. GIS Posidonie, Marseille: 169-178. 